Andrews University

Digital Commons @ Andrews University

Faculty Publications

3-1-2004

\title{
A Comparison of Four Electrical Stimulation Types on Staphylococcus Aureus Growth in Vitro
}

\author{
Harold L. Merriman \\ Andrews University \\ Chris A. Hegyi \\ Andrews University \\ Cheryl R. Albright-Overton \\ Andrews University \\ John Carlos Jr. \\ Andrews University, carlosjj@andrews.edu \\ Robert W. Putnam \\ Wright State University
}

See next page for additional authors

Follow this and additional works at: https://digitalcommons.andrews.edu/pubs

Part of the Physical Therapy Commons

\section{Recommended Citation \\ Merriman, Harold L.; Hegyi, Chris A.; Albright-Overton, Cheryl R.; Carlos, John Jr.; Putnam, Robert W.; and Mulcare, Janet A., "A Comparison of Four Electrical Stimulation Types on Staphylococcus Aureus Growth in Vitro" (2004). Faculty Publications. 2115. \\ https://digitalcommons.andrews.edu/pubs/2115}

This Article is brought to you for free and open access by Digital Commons @ Andrews University. It has been accepted for inclusion in Faculty Publications by an authorized administrator of Digital Commons @ Andrews University. For more information, please contact repository@andrews.edu. 


\section{Authors}

Harold L. Merriman, Chris A. Hegyi, Cheryl R. Albright-Overton, John Carlos Jr., Robert W. Putnam, and Janet A. Mulcare 


\title{
A comparison of four electrical stimulation types on Staphylococcus aureus growth in vitro
}

\author{
Harold L. Merriman, PhD, MPT; Chris A. Hegyi, MPT; Cheryl R. Albright-Overton, MPT; \\ John Carlos, Jr, PhD, PT; Robert W. Putnam, PhD; Janet A. Mulcare, PhD \\ Master of Physical Therapy Program, Andrews University, and Department of Physiology and Biophysics, \\ Wright State University, Dayton, $\mathrm{OH}$
}

\begin{abstract}
We evaluated the efficacy of common electrical stimulation (ES) types on bacterial growth in vitro using clinically relevant conditions. Four types of ES-continuous microamperage direct current ( $\mu \mathrm{ADC}$ ), high-voltage pulsed current (HVPC), low-voltage monophasic milliamperage pulsed current (LVMmAPC), and low-voltage biphasic milliamperage pulsed current (LVBmAPC) - were each applied to a separate set of culture plates containing Staphylococcus aureus for $1 \mathrm{~h}$ at $37{ }^{\circ} \mathrm{C}$ on three consecutive days. After ES treatment, the zone of inhibition surrounding each electrode was measured. Zone of inhibition measurements showed a significant inhibitory effect for continuous $\mu \mathrm{ADC}$ and HVPC $(p<0.05)$, but not for LVMmAPC and LVBmAPC. Differences in bacterial growth inhibition were not found for polarity and time. These data suggest that for infected wounds, HVPC and continuous $\mu \mathrm{ADC}$ treatments may have an initial bacterial inhibitory effect, which does not significantly change with subsequent treatments.
\end{abstract}

Key words: bacteria, electrical stimulation, wound healing.

\section{INTRODUCTION}

For decades, a variety of electrical stimulation (ES) types have been used to promote wound healing [1-3]. Possible mechanisms that may account for enhanced wound healing include bactericidal and bacteriostatic effects [4-6], increased blood flow [7], orientation of new collagen formation [8], and retardation of edema buildup [9]. The influence of ES on wound healing has been assessed in a number of clinical trials that examined continuous microamperage direct current ( $\mu \mathrm{ADC}$ ) $[10,11]$, pulsed $\mu \mathrm{ADC}[12,13]$, pulsed milliamperage direct current (mADC) [14-16], and high-voltage pulsed current (HVPC) [17-21], all of which have demonstrated evidence of decreased wound healing time by using ES.

According to the clinical practice guidelines developed by the U.S. Department of Health and Human Services Agency for Healthcare Research and Quality (formerly the Agency for Health Care Policy and Research), ES is the only adjunctive therapy recommended to enhance healing of recalcitrant (stage II) and

\footnotetext{
Abbreviations: $\mathrm{AC}=$ alternating current, $\mathrm{ANOVA}=$ analysis of variance, $\mathrm{DC}=$ direct current, $\mathrm{ES}=$ electrical stimulation, HVPC = high-voltage pulsed current, LVBmAPC = low-voltage symmetrical biphasic milliamperage pulsed current, LVM$\mathrm{mAPC}=$ low-voltage monophasic milliamperage pulsed current, $\mathrm{mADC}=$ milliamperage direct current, $\mu \mathrm{ADC}=$ microamperage direct current, $\mathrm{PBS}=$ phosphate-buffered saline, $\mathrm{PC}=$ pulsed current, $\mathrm{pps}=$ pulses per second, $\mathrm{TSB}=$ trypticase soy broth.

This material is based on work supported by the Department of Veterans Affairs, Rehabilitation Research and Development Service, Washington, DC.

Address all correspondence to Harold L. Merriman, PhD, MPT, Master of Physical Therapy Program, Andrews University, 2912 Springboro West, Dayton, OH 45439; 937-2982878; fax: 937-298-9500; email: merrimah@andrews.edu.
} 
refractory (stage III and IV) pressure ulcers [22]. A recent study by Houghton et al. indicates that ES can accelerate wound closure of chronic leg ulcers caused by diabetes and arterial and venous insufficiency [21]. Any acceleration of chronic ulcer closure would naturally result in economic savings and decreased amputation rates [23]. Thus, there is growing evidence to support ES in treating chronic wounds that have not responded to conventional treatment of wound debridement, cleansing, dressing, and infection treatment, including antibiotics.

Attempts to determine the effects of ES on bacteria commonly found in wounds have resulted in the publication of several in vitro studies. In these studies, various ES types have been employed, including continuous $\mu$ ADC $[4,24]$, continuous mADC [24,25], and HVPC [25-27]. Although considerable evidence indicates that bacterial growth is inhibited by ES, in vitro studies to date have employed a variety of conditions and have yielded conflicting results due to the diverse nature of methodology. In addition, many of these studies have employed parameters that fall outside the range of practical clinical usage.

A single in vitro model that allows direct comparison between the various electrical stimulation types on bacterial growth is needed to establish which ES type is most effective while using clinical parameters. The only study to directly compare ES types in vitro was performed by Guffey and Asmussen, who found a bacterial inhibitory effect for continuous $\mu$ ADC, but not HVPC [25]. For HVPC they chose to vary amplitude over a range that would likely produce an uncomfortable motoric response in the patient. Although a number of ES types have been shown in clinical trials to increase the rate of wound healing, not all of them have been studied in vitro. In addition, all the in vitro studies have measured the antibacterial effect of only a single ES treatment, whereas clinical trials have used multiple ES treatments to accelerate wound healing $[2,28,29]$.

We investigated four types of ES that have been shown in clinical trials to accelerate wound healing in humans: continuous $\mu$ ADC, HVPC, low-voltage monophasic milliamperage pulsed current (LVM$\mathrm{mAPC}$ ), and low-voltage symmetrical biphasic milliamperage pulsed current (LVBmAPC). Therefore, the purpose of our study was to test these four ES types with clinically relevant parameters over three consecutive days with a single in vitro model to allow direct comparison of the antibacterial effectiveness of each type.

\section{METHODS}

\section{Materials}

We obtained exponential growth-phase clinical isolates of Staphylococcus (S.) aureus B41 $\beta$-lactamase positive from Pam Fink of Wright State University, Dayton, $\mathrm{OH}$. Two holes were bored through the bottom of each plastic $60 \mathrm{~mm}$ petri dish $1.5 \mathrm{~cm}$ apart from the center. Two $5.4 \mathrm{~cm}$, 0.042-gauge stainless steel wires (Phoenix Wire Cloth, Inc., Troy, MI) were fed through each hole. A $1.2 \mathrm{~cm}$ portion of the electrode inside the dish was perpendicular to the bottom of the dish, while the outside portion was anchored with epoxy cement parallel to the bottom of the dish, with a $2 \mathrm{~cm}$ overhang for attachment to the ES device (Figure 1). Dishes were then sterilized overnight in a laminar flow hood with a built-in germicidal ultraviolet light. A custom-made wooden rack was designed to allow stacking of four sets of petri dishes, with four dishes per set (Figure 2). The rack was prewarmed in the incubator before application of ES to prevent it from acting as a heat sink once it was put into the incubator.

\section{Instrumentation}

The following ES devices were used in the study to apply the four types of current to the culture dishes.

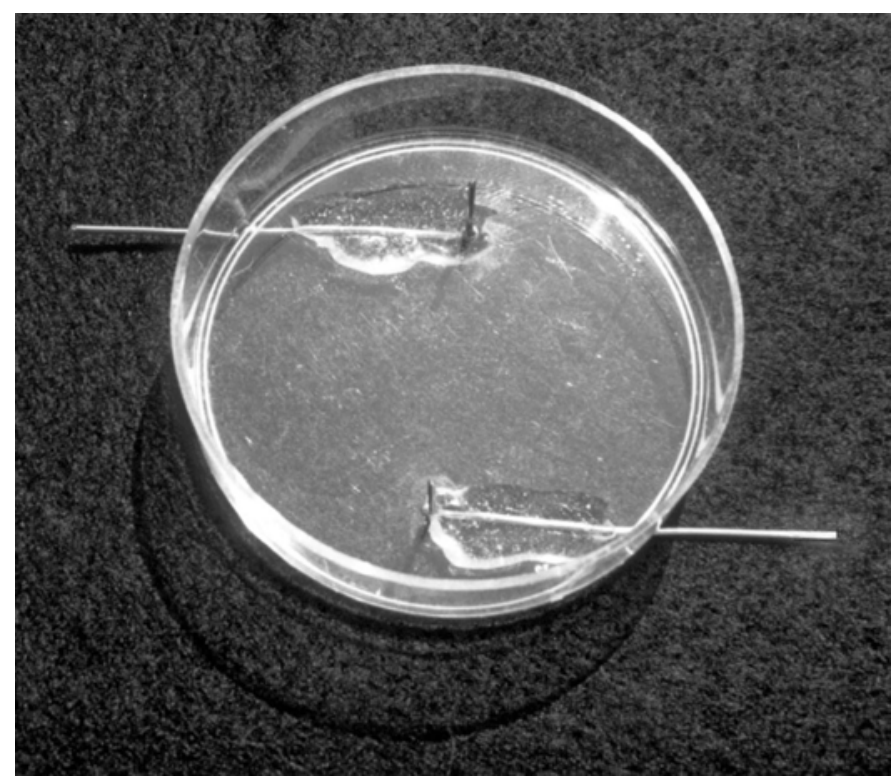

Figure 1.

Petri dish $(60 \mathrm{~mm})$ with stainless-steel electrodes externally anchored with epoxy cement. 


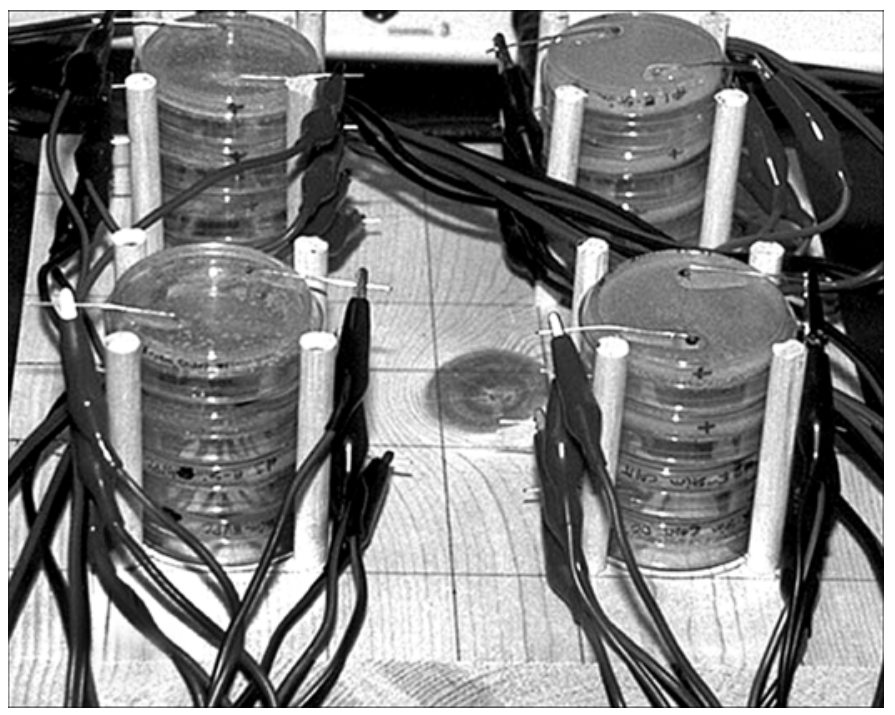

Figure 2.

Culture plate setup in wooden rack with lead wires connected before placement into incubator.

Continuous $\mu$ ADC was applied with a Sys*Stim ${ }^{\circledR} 206$ muscle stimulator (model ME206, Mettler Electronics Corp., Anaheim, CA). HVPC was applied with an Omnistim ${ }^{\circledR} 500$ ES device (model 100500, International Academy of Physiotherapeutics, Inc., Topeka, KS), while LVMmAPC and LVBmAPC were applied with a Forte ${ }^{\circledR}$ ES device (model 074122, Chattanooga Group, Inc., Hixson, TN). Special bifurcated cables with alligator clips were fabricated to allow simultaneous delivery of current to four petri dishes with each ES type. Current output from the ES device was increased fourfold to provide the desired current level at each petri dish. The cables were tested for uniformity in transmission of electrical current with an oscilloscope and a multitester.

\section{Procedure}

S. aureus cultures were grown overnight to reach midexponential growth phase at $37^{\circ} \mathrm{C}$ in trypticase soy broth (TSB) with a shaking incubator. The following day, $10 \mathrm{~mL}$ of 1.0-percent agarose in $0.1 \mathrm{M}$ phosphate-buffered saline (PBS) and TSB containing $10^{6}$ colony-forming units per milliliter of $S$. aureus were added to each sterile $60 \mathrm{~mm}$ petri dish [27]. Culture plates were used immediately after solidification.

Four petri dishes (one set) plated with $S$. aureus were each stimulated with one of the following electrical stimulation types: (1) continuous $\mu \mathrm{ADC}$ at $500 \mu \mathrm{A}$, (2) LVMmAPC at $30 \mathrm{~mA}$ and 128 pulses per second (pps),
(3) LVBmAPC at $30 \mathrm{~mA}$ and $128 \mathrm{pps}$, and (4) HVPC at $250 \mathrm{~V}$ and 100 pps with an intraphase interval of $70 \mu \mathrm{s}$ (Figure 3). Each ES type was applied to a corresponding set of four petri dishes for $1 \mathrm{~h}$ at $37^{\circ} \mathrm{C}$ on consecutive days 1 , 2, and 3. Following each ES treatment, the petri dishes were incubated for another $23 \mathrm{~h}$ at $37^{\circ} \mathrm{C}$, after which the diameter of the zone of inhibition (i.e., absence of bacterial growth) surrounding each electrode was measured to the nearest tenth of a millimeter by two investigators using calipers. Two separate measurements of each zone were taken by each investigator, one parallel and one perpendicular to the electrode. These measurements were then averaged to obtain a value for the zone of inhibition. Inter-tester reliability was determined using a $2 \times 2$ repeated measures analysis of variance (ANOVA). Each petri dish was also examined for electrode corrosion, gas formation, and media discoloration. A control set of four petri dishes, with bacteria but without ES, was incubated and measured as above. An additional control group of four petri dishes without bacteria underwent all procedures and was used to monitor the $\mathrm{pH}$ of each electrical stimulation type. Photographs were taken for reference purposes.

On each of the three days, one of the $\mathrm{pH}$ control culture plates from each group was used to determine the $\mathrm{pH}$ of that group. To do this, $1 \mathrm{~mL}$ of chemical $\mathrm{pH}$ indicator, a mixture of 0.01-percent methyl red (weight per volume) and 0.01-percent thymol blue was pipetted directly onto the agar culture plate. The chemical $\mathrm{pH}$ indicator was applied at 6 min after ES removal, and the $\mathrm{pH}$ color was recorded at $20 \mathrm{~min}$ after ES was terminated. This indicator gave a color, showing a range of $\mathrm{pH}$ as follows: (1) dark red for a $\mathrm{pH}$ of 4.4, (2) lighter red for a $\mathrm{pH}$ of 4.4 to 6.2, (3) yellow for a $\mathrm{pH}$ of 6.2 to 8.0 , and (4) purple for a pH of 8.0 [27].

\section{Statistical Design}

A $2 \times 5 \times 3$ repeated measures ANOVA, $p<0.05$, was performed to determine a possible main effect for (1) electrode polarity between two levels, (2) type of ES treatment between each of five levels (four types of electrical stimulation and the control group), and (3) time within each of three levels (three treatment days).

\section{RESULTS}

Growth inhibition of $S$. aureus, represented by the measurements of the zones of inhibition, is shown in 
(a)

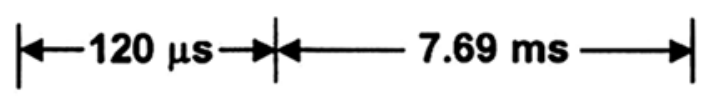

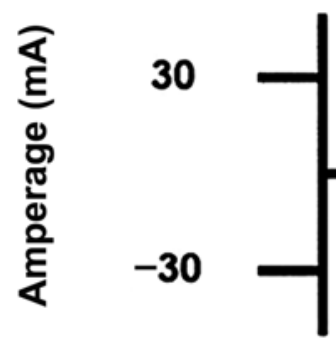

(b)

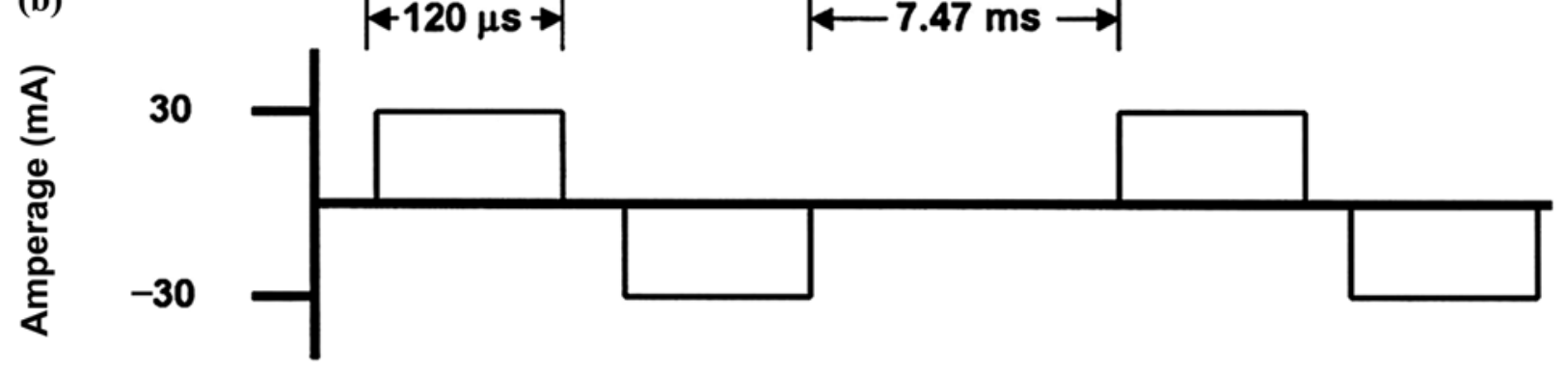

(c)

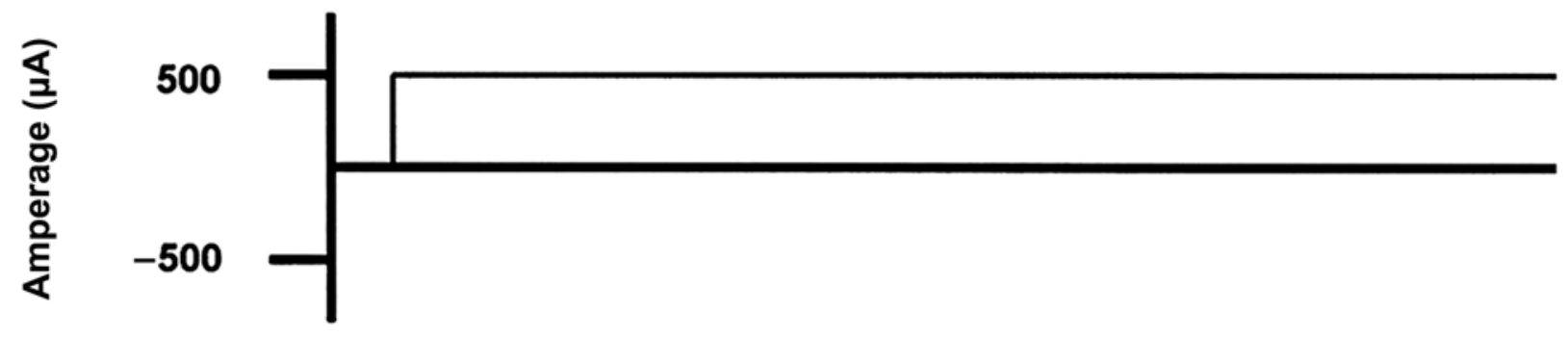

(d)

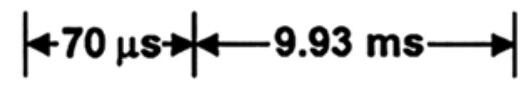

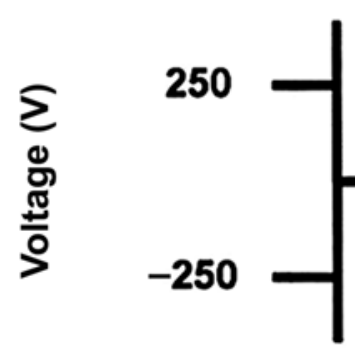

Figure 3.

Graphic representation of waveforms showing duration and current amplitude or voltage: (a) low-voltage monophasic milliamperage pulsed current at 128 pulses per second (pps); (b) low-voltage symmetrical biphasic milliamperage pulsed current at 128 pps; (c) continuous microamperage direct current; and (d) high-voltage pulsed current at 100 pps. 
Table 1 for each of the three variables: type of electrical stimulation, electrode polarity, and treatment day. Each entry represents the average of all four culture plates in each respective group. An inhibitory effect was found for HVPC and continuous $\mu$ ADC at both poles over all three days, while no effects were found for LVMmAPC or LVBmAPC at either pole for any treatment day. No inhibitory effects were found in the control culture plates that contained bacteria but were not subjected to ES.

ANOVA results revealed that a main effect was found for stimulation type, but not for treatment day or polarity. An all-pairwise multiple comparison using the Student-Newman-Keuls method indicated that the zone of inhibition was significantly greater for HVPC than all other conditions $(p<0.05)$. Furthermore, continuous $\mu \mathrm{ADC}$ stimulation, while significantly lower than HVPC, was also significantly better than LVMmAPC, LVB$\mathrm{mAPC}$, and the control condition. There was no interaction between technicians and electrical stimulation types. To evaluate inter-tester reliability, we performed a $2 \times 2$ repeated measures ANOVA and found no significant main effect for technician. An intraclass correlation coefficient (ICC) $(3,1)$ was performed to examine agreement between technicians. The results showed an ICC $=0.72$.

Table 2 represents the physical and chemical changes found at the electrodes. Electrode corrosion and discoloration of the medium were found at the anode, and gas formation occurred at the cathode with HVPC and continuous $\mu \mathrm{ADC}$. Furthermore, the $\mathrm{pH}$ at the anode

Table 1.

Mean $( \pm S D)$ for diameters of zones of inhibition for each condition.

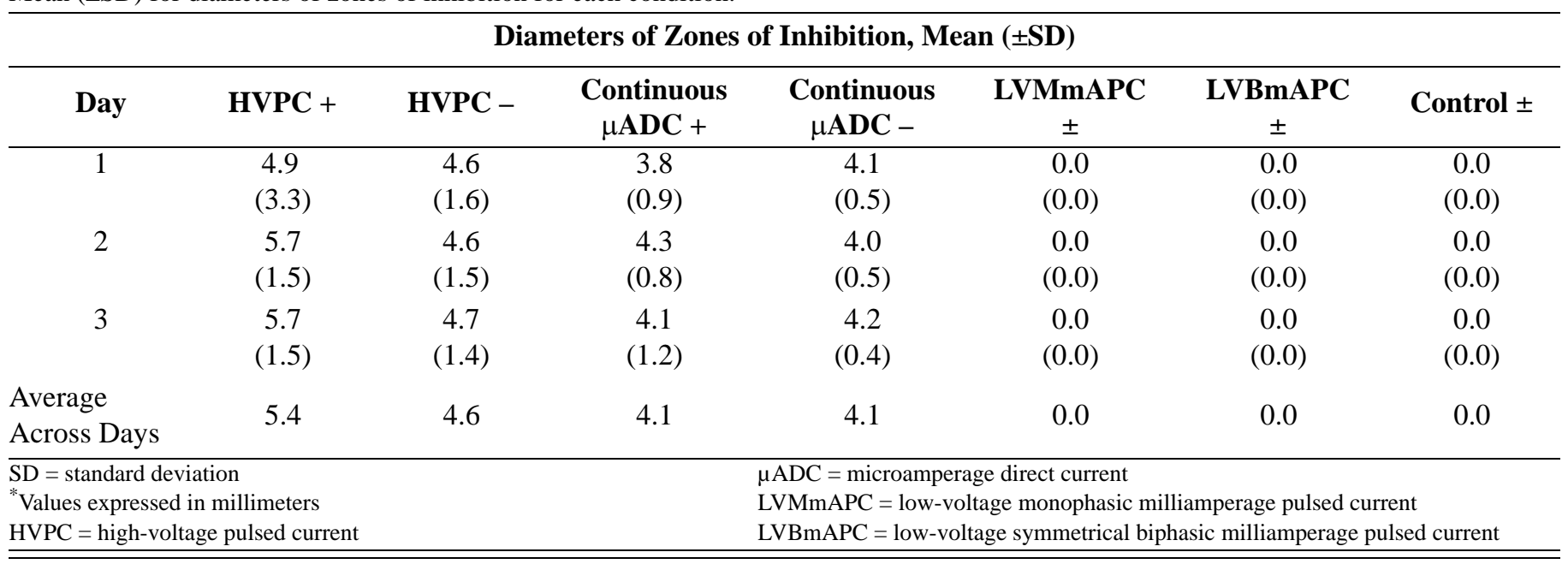

Table 2.

Chemical and physical changes at electrodes found across three treatment days.

\begin{tabular}{|c|c|c|c|c|c|}
\hline Electrical Stimulation & Pole & Corrosion & Discoloration & Gas Formation & pH \\
\hline HVPC & + & Large pitting & Present & - & $\leq 4.4^{*}, 4.4-6.2^{\dagger}$ \\
\hline HVPC & - & - & - & Bubbles & $\geq 8.0$ \\
\hline$\mu \mathrm{ADC}$ & - & - & - & Bubbles $^{\dagger}$ & $\geq 8.0$ \\
\hline LVMmAPC & \pm & - & - & - & $6.2-8.0$ \\
\hline Control & \pm & - & - & - & $6.2-8.0$ \\
\hline \multicolumn{3}{|c|}{$\begin{array}{l}{ }^{*} \text { Characteristic observed only on day } 1 \\
{ }^{\dagger} \text { Characteristic observed only on days } 2 \& 3 \\
-=\text { No effect found for all } 3 \text { days } \\
\text { HVPC = high-voltage pulsed current }\end{array}$} & \multicolumn{3}{|c|}{$\begin{array}{l}\mu \mathrm{ADC}=\text { microamperage direct current } \\
\mathrm{LVMmAPC}=\text { low-voltage monophasic milliamperage pulsed current } \\
\text { LVBmAPC = low-voltage symmetrical biphasic milliamperage pulsed current }\end{array}$} \\
\hline
\end{tabular}


tended to be acidic, while the $\mathrm{pH}$ at the cathode was alkaline. These effects were found across all three treatment days unless otherwise indicated. No effects were found with the control, LVMmAPC, and LVBmAPC dishes at either pole for any treatment day.

\section{DISCUSSION}

Various types of ES have produced a bacterial inhibitory effect in a number of in vitro studies that use diverse systems and parameters [4,24-29]. Using a single in vitro system, we found a bacterial inhibitory effect for HVPC and continuous $\mu \mathrm{ADC}$ at both poles with conditions that can be easily administered in the clinic. In addition, the bacterial inhibitory effect was not significantly different among days 1 to 3 or between anodal and cathodal polarity.

Continuous $\mu \mathrm{ADC}$ was the first type of ES to be systematically studied for antibacterial effects in vitro [24]. Both Barranco et al. [4] and Guffey and Asmussen [25] found a bactericidal effect with continuous $\mu \mathrm{ADC}$ using $S$. aureus in an in vitro model. Barranco et al. used a time frame of $48 \mathrm{~h}$ that is not practical to use in the clinic. Guffey and Asmussen observed a bacterial inhibitory effect at both electrodes using a treatment time of $30 \mathrm{~min}$ and amplitudes of 5 and $10 \mathrm{~mA}$, but not with the cathode at $1 \mathrm{~mA}$. Our study is the first in vitro study to show a bacterial inhibitory effect at $500 \mu \mathrm{A}$ applied for $1 \mathrm{~h}$. These parameters are similar to those used by several clinical studies that showed increased ulcer healing rates with the use of continuous $\mu \mathrm{ADC}[10,11]$.

Previous HVPC in vitro studies have shown considerable variability in their effects on bacterial growth. For example, Guffey and Asmussen failed to observe inhibition of S. aureus at either electrode using HVPC [25]. They used a shortened treatment time of 30 min, which may explain their results. Kincaid and Lavoie observed bactericidal effects at both electrodes using an in vitro HVPC system on several bacterial species: $S$. aureus, Escherichia coli, and Pseudomonas aeruginosa [26]. They required a minimum of $2 \mathrm{~h}$ of exposure at $250 \mathrm{~V}$ to observe bacterial growth inhibition. We observed a bacterial inhibitory effect after only $1 \mathrm{~h}$ at $250 \mathrm{~V}$. This may be explained by our use of a different medium and/or bacterial density. Using $S$. aureus and a TSB/PBS culture medium like our system, Szuminsky et al. found bacterial inhibition at both electrodes with a setting of $500 \mathrm{~V}$ for $30 \mathrm{~min}$ [27]. While $500 \mathrm{~V}$ is generally intolerable for patients, $250 \mathrm{~V}$ is tolerable if the interpulse interval is sufficiently long. In addition, many HVPC devices do not have settings above 250 to $300 \mathrm{~V}$. Our HVPC study is the first to demonstrate a direct bacterial inhibitory effect with both electrodes, using conditions that are clinically practical.

We did not observe any bacterial inhibitory effects for either LVMmAPC or LVBmAPC using our in vitro system. Rowley found that alternating current (AC), unlike direct current (DC), did not affect bacterial growth rates [24]. Both AC and LVBmAPC produce a waveform that is biphasic in nature. The main difference is that $\mathrm{AC}$ is a sinusoidal waveform, whereas biphasic pulsed current (PC) consists of isolated electrical events (pulses). However, because the phases of AC and symmetrical biphasic PC are charge balanced, neither of these current types produces a $\mathrm{pH}$ change nor a polarity effect. Thus, it is not surprising that we observed no bacterial inhibitory effect for LVBmAPC. Our results suggest that any beneficial in vivo healing effect observed for LVMmAPC and LVBmAPC is not caused by a bacterial inhibitory effect, but by enhancing other wound-healing mechanisms [14].

As expected, control dishes that were plated with bacteria but not subjected to ES showed no bacterial inhibitory effect (Table 1). This indicates that components in the stainless steel do not diffuse into the medium if no current is applied. Studies have shown that ions or other factors can diffuse into the medium after a current is applied to produce indirect effects that can inhibit bacterial growth [2]. For example, the bactericidal effect produced by anodal $\mu \mathrm{ADC}$ on intact skin appears to be electrochemical in origin [30].

Gas formation at the cathode and corrosion and discoloration of the medium at the anode were observed for both HVPC and continuous $\mu$ ADC (Table 2). These findings are similar to those of Barranco et al. [4]. This suggests that physical changes occur with ES treatment in the area immediately surrounding the electrodes.

We chose to use $S$. aureus in this study because it is a common bacterial species isolated from chronic, infected wounds [29,31] and has been extensively studied in vitro [4,25-29]. We also selected $S$. aureus because it is a Gram-positive bacteria, and it appears to be more resistant to ES than Gram-negative bacteria, such as Pseudomonas aeruginosa. This enhanced resistance of Gram-positive bacteria is perhaps due to its cell wall thickness/composition, and explains why ES may produce a bacteriostatic effect with Gram-positive bacteria 
versus a bactericidal effect with Gram-negative bacteria [29]. Thus, we believed that $S$. aureus would be a good initial indicator to test the effectiveness of various ES types in our system.

A limitation of this study was that only one type of electrode (stainless steel) was used. Barranco et al. compared several types of electrodes (silver, platinum, stainless steel, and gold) using an in vitro system and found that the positive silver electrode provided the highest level of bacterial inhibition and lowest level of toxicity [4]. Other studies have used a variety of electrode types, including aluminum [17,21] and silver [6,20,28,29]. In our study, we chose stainless-steel electrodes because of their cost-effectiveness and common use in previous studies [14,25-27]. Our system provided a convenient platform in future studies for comparing the antibacterial effects of various electrode types.

The in vitro model system we used in this study has several advantages compared to those used in previous studies. (1) The wood rack used to hold the culture plates allowed us to simultaneously treat up to 16 culture plates. The rack also allowed us to conveniently treat the culture plates with ES in an incubator at $37^{\circ} \mathrm{C}$. (2) Insertion of the electrode through the bottom of the petri dish and application of epoxy cement to secure it produced a very durable platform that allowed us to provide multiple treatments on each dish. (3) This system allowed for the direct comparison of multiple ES types, which helped control for environmental and reagent factors.

Further studies are needed to determine the contribution of indirect effects on the zones of bacterial inhibition. In vitro HVPC studies have shown that when bacteria are plated after ES is applied, a bactericidal effect can occur $[26,27]$. Compared to the closed in vitro system investigated in our study, the wound environment in humans is much more complex. Wound healing in humans depends on a variety of exogenous and endogenous factors, including bacterial load, the amount of devitalized tissue, the magnitude of inflammation, and the degree of tissue perfusion [32]. Human wounds may constantly receive a new supply of highly buffered fluid that can mask the exact nature of the bacterial inhibitory effect achieved by ES. However, future studies using our in vitro model system that allows the simultaneous testing of multiple conditions should help determine the nature of indirect bacterial inhibitory effects, as well as help replicate more complex wound environments.

\section{CONCLUSION}

The purpose of this investigation was to study four types of ES used to enhance wound healing rates in vivo, and to determine their effect on bacterial growth with a single in vitro system. A statistically significant bacterial inhibitory effect was found for continuous $\mu \mathrm{ADC}$ and HVPC, but not for LVMmAPC and LVBmAPC. Differences in bacterial growth inhibition were not found for polarity and time. These findings support the idea that a bacterial inhibitory effect may contribute to enhanced wound healing rates observed with continuous $\mu \mathrm{ADC}$ and HVPC, although this effect remains to be shown in vivo or in clinical wounds.

\section{ACKNOWLEDGMENTS}

We thank Phyllis Douglas at Wright State University, David Delang at Kettering College of Medical Arts, and Stephen Nyirady at Southern Adventist University for their laboratory expertise; Kevin Wallewein at Andrews University for providing technical assistance; and Brad Rudolph at Rudolph Medical Equipment for loan of the Sys*Stim ES device.

\section{REFERENCES}

1. Kanof N. Gold leaf in the treatment of cutaneous ulcers. J Invest Dermatol 1964;43:441-42.

2. Kloth LC. Electrical stimulation in tissue repair. In: McCulloch JM, Kloth LC, Feedar JA, editors. Wound healing: alternatives in management. Philadelphia: F.A. Davis Co; 1995. p. 275-314.

3. Newton R. High-voltage pulsed current: theoretical bases and clinical applications. In: Nelson RM, Currier DP, editors. Clinical electrotherapy. 2nd ed. East Norwalk, CT: Appleton \& Lange; 1991. p. 201-20.

4. Barranco SD, Spadaro JA, Berger TJ, Becker RO. In vitro effect of weak direct current on Staphylococcus aureus. Clin Orthop 1974;100:250-55.

5. Rowley BA, McKenna JM, Chase GR. The influence of electrical current on an infecting microorganism in wounds. Ann NY Acad Sci 1974;238:543-51.

6. Chu CS, McManus AT, Pruitt BA Jr, Mason AD Jr. Therapeutic effects of silver nylon dressings with weak direct current on Pseudomonas aeruginosa-infected burn wounds. J Trauma 1988;28:1488-92. 
7. Mohr T, Akers TK, Wessman HC. Effect of high-voltage stimulation on blood flow in the rat hind limb [published erratum appears in Phys Ther 1987;67:979]. Phys Ther 1987;67:526-33.

8. Reger SI, Hyodo A, Hegami S, Kambic HE, Sahgal V. Experimental wound healing with electrical stimulation. Artif Organs 1999;23:460-62.

9. Reed BV. Effect of high voltage pulsed electrical stimulation on microvascular permeability to plasma proteins: possible mechanism in minimizing edema. Phys Ther 1988;68:491-95.

10. Carley PJ, Wainapel SF. Electrotherapy for acceleration of wound healing: low intensity direct current. Arch Phys Med Rehabil 1985;66:443-46.

11. Gault WR, Gatens PF Jr. Use of low intensity direct current in management of ischemic skin ulcers. Phys Ther 1976; 56:265-69.

12. Barron JJ, Jacobson WE, Tidd G. Treatment of decubitus ulcers: a new approach. Minn Med 1985;68:103-6.

13. Wood JM, Evans PE 3rd, Schallreuter KU, Jacobson WE, Sufit R, Newman J, et al. A multicenter study on the use of pulsed low intensity direct current for healing chronic stage II and III decubitus ulcers. Arch Dermatol 1993;129:999-1009.

14. Feeder JA, Kloth LC, Gentzkow GD. Chronic dermal ulcer healing enhanced with monophasic pulsed electrical stimulation. Phys Ther 1991;71:639-49.

15. Gentzkow GD, Pollack SV, Kloth LC, Stubbs HA. Improved healing of pressure ulcers using Dermapulse, a new electrical stimulation device. Wounds 1991;3:158-70.

16. Gentzkow GD, Alon G, Taler GA, Eltorai IM, Montroy RE. Healing of refractory stage III and IV pressure ulcers with a new electrical stimulation device. Wounds 1993; 5:160-72.

17. Griffen JW, Tooms RE, Mendius RA, Clifft JK, Zwaag RV, El-Zecky F. Efficacy of high voltage pulsed current for healing of pressure ulcers in patients with spinal cord injury. Phys Ther 1991;71:433-42.

18. Kloth LC, Feedar JA. Acceleration of wound healing with high voltage, monophasic, pulsed current. Phys Ther 1988; 68:503-8.

19. Gogia PP, Marquez RR, Minerbo GM. Effects of high voltage galvanic stimulation on wound healing. Ostomy Wound Manage 1992;38:29-35.

20. Peters EJ, Lavery LA, Armstrong DG, Fleischli JG. Electric stimulation as an adjunct to heal diabetic foot ulcers: a ran- domized clinical trial. Arch Phys Med Rehabil 2001;82: 721-25.

21. Houghton PE, Kincaid CB, Lovell M, Campbell KE, Keast DH, Woodbury MG, et al. Effect of electrical stimulation on chronic leg ulcer size and appearance. Phys Ther 2003; 83:17-28.

22. Bergstrom N, Bennett MA, Carlson CE, Allman RM, Alvarez OM, Frantz RA. Clinical practice guideline No. 15: treatment of pressure ulcers. Rockville, MD: US Department of Health and Human Services, Public Health Services, Agency for Health Care Policy and Research; 1994: 55-56. AHCPR Publication 95-0652.

23. Tennvall GR, Apelqvist J, Eneroth M. Costs of deep foot infections in patients with diabetes mellitus. Pharmacoeconomics 2000;18:225-38.

24. Rowley BA. Electrical current effects on E. coli growth rates. Proc Soc Exp Biol Med 1972;139:929-34.

25. Guffey JS, Asmussen MD. In vitro bactericidal effects of high voltage pulsed current versus direct current against Staphylococcus aureus. J Clin Electrophysiol 1989;1:5-9.

26. Kincaid CB, Lavoie KH. Inhibition of bacterial growth in vitro following stimulation with high voltage, monophasic, pulsed current. Phys Ther 1989;69:651-55.

27. Szuminsky NJ, Albers AC, Unger P, Eddy JG. Effect of narrow, pulsed high voltages on bacterial viability. Phys Ther 1994;74:660-67.

28. Ong PC, Laatsch LJ, Kloth LC. Antibacterial effects of a silver electrode carrying microamperage direct current in vitro. J Clin Electrophysiol 1994;6:14-18.

29. Laatsch LJ, Ong PC, Kloth LC. In vitro effects of two silver electrodes on select wound pathogens. J Clin Electrophysiol 1995;7:10-15.

30. Bolton L, Foleno B, Means B, Petrucelli S. Direct-current bactericidal effect on intact skin. Antimicrob Agents Chemother 1980;18:137-41.

31. Finegold SM, Martin WJ, Scott EG. Bailey and Scott's diagnostic microbiology. St. Louis: C.V. Mosby Co.; 1978.

32. Bowler P. Wound pathophysiology, infection and therapeutic options. Ann Med 2002;34:419-27.

Submitted for publication January 6, 2003. Accepted in revised form May 28, 2003. 